\title{
New and Interesting Records of South African Fungi, Part VI
}

\author{
by \\ G. C. A. van der Westhuizen* and K. T. van Warmelo*
}

\begin{abstract}
Six species of fungi, recorded for the first time in South Africa, are described. The species are Gelasinospora cerealis Dowding from roots of Eucalyptus saligna; Spegazzinia tessarthra (B. \& C.) Saccardo from Zea mavs; Melampsora larici-populina Klebahn from Populus deltoides; Saccobolus depauperatus (Berk. \& Br.) Phill. from horse dung; Humicola stellata Bunce from grass hay and Chaetomium cochliodes Palliser from garden soil.
\end{abstract}

Six species are described and discussed below. Dried down cultures or specimens on natural substrata of all these species have been deposited in the mycological collection of the National Herbarium (PRE), at 590 Vermeulen Street, Pretoria.

1. Gelasinospora cerealis Dowding in Can. J. Res. C. 9: 295 (1933): Cain, ibid. 28: 566 (1950); Von Arx and Müller, Beitr. Kryptogamenfl. Schweiz 11: 293 (1954).

Figures : 1, 2, 3, 4.

On potato-dextrose agar colonies grow rapidly covering the plate in 3-4 days and forming a cottony to woolly, white mycelial mat. Perithecia single or cespitose, superficial or with base partly immersed, dark brown or black, pyriform, bare over upper parts but with dense mycelium towards the base, $800-1100 \times 600-900 \mu$; neck papilliform $180-250 \mu$ long and $180-250 \mu$ wide at the base, ostiolate and lined with periphyses; wall thick coriaceous composed of dark-brown, angular cells externally and subhyaline cells in the inner layers. Asci cylindrical, hyaline, unitunicate, truncate and distinctly perforate at the apex tapering below into a fairly short stipe, $175-280 \times 22 \cdot 5-37 \cdot 0 \mu$, eight spored, or, sterile olivaceous-brown, thick-walled and pitted, 137-205 $\times 20-25 \mu$; paraphyses lacking but hyaline, irregular, elongate, thin-walled, cells and narrow, hyaline thinwalled filaments up to $3 \cdot 0 \mu$ in diameter are present among the asci. Ascospores uniseriate, hyaline at first soon darkening to pale brown or olivaceous and developing a thick pitted epispore which darkens to deep olivaceous black, finally opaque, broadly ellipsoid, rounded at the ends, occasionally slightly apiculate at one end, 25-40 $\times 20-27 \cdot 5$ $\mu$ mostly $32 \times 25 \mu$.

Specimen examined: PRE 43070, (Mycological Herbarium) on potato-dextrose agar, isolated from diseased roots of Eucalyptus saligna, Tzaneen, Northern Transvaal, March 1964.

The dark-coloured ascospores with thick, pitted epispore of this fungus are characteristic of the genus Gelasinospora Dowding of which four species have been described. These have been recorded on dung, roots and stems of various plants (Von Arx and Müller, l.c.).

\footnotetext{
* Plant Protection Research Institute, Private Bag 134, Pretoria.
} 


\section{ExPlanation OF Figures}

FIG. 1-4.-Gelasinospora cerealis. Fig. 1, perithecia $(\times 15)$. Fig. 2, young ascus and ascospores $(\times 400)$. Fig. 3, dark coloured, sterile ascus $(\times 400)$. Fig. 4, maturing ascospore showing pitted epispore $(\times 500)$.

FIG. 5-6.-Spegazzinia tessarthra. Fig. 5, conidium without spines $(\times 500)$. Fig. 6, echinulate conidium $(\times 500)$.

FiG. 7-8.-Melampsora larici-populina. Fig. 7, capitate paraphysis showing thickened wall $(\times 1000)$. Fig. 8, uredospore $(\times 1000)$.

FIG. 9-12.-Saccobolus depauperatus. Fig. 9, details of hymenium showing immature ascospores and paraphyses $(\times 520)$. Fig. 10, single ascus $(\times 520)$. Fig. 11, operculum after ascospore release $(\times 520)$. Fig. 12, mature ascospore cluster after release showing mucilaginous capsule $(\times 520)$.

Fig. 13-14.- Humicola stellata.-Fig. 13, detail of conidiophore and conidium $(\times 1500)$. Fig. 14, mature conidia showing variation in shape $(\times 1500)$. 


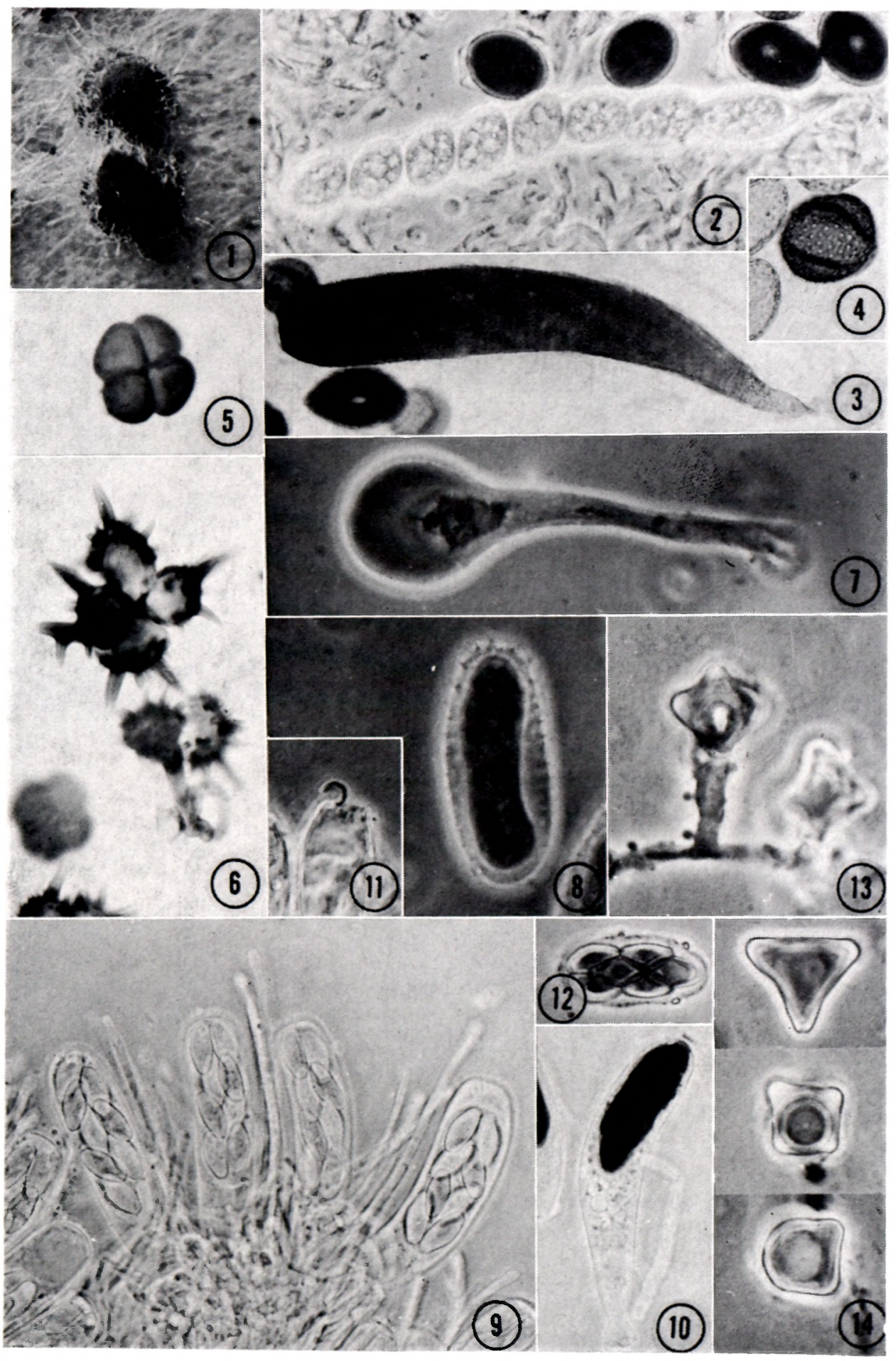


The fungus described here agrees best with Dowding's (l.c.) description of $G$. cerealis but differs somewhat in having larger perithecia than in the original description. This is an unimportant difference since it was noticed that the perithecia formed on diluted potato-dextrose agar were much smaller. The range of dimensions given here for the asci and spores are wider than those in the descriptions by Dowding (l.c.), Cain (l.c.) and Von Arx and Müller (l.c.). The dimensions given above cover those given by these authors, but do not overlap with the dimensions for the closely related species, $G$. calospora (Mouton) C. et M. Moreau which has smaller, more elongate spores than G. cerealis.

The dark-coloured, thick-walled sterile asci described above were seen frequently in cultures of the South African isolate. In the young state these could be distinguished by the absence of differentiated contents and early thickening and pitting of their walls while still hyaline. Later, they turn almost as dark as the spores and their numbers increase as the cultures age. Dodge (Mycologia 26: 360-376, 1934) figured similar dark-coloured indurate, sterile asci from cultures of Neurospora tetrasperma irradiated with X-rays. This ascus abortion was found to be due to a lethal factor which was carried over to new generations by ascospores containing two nuclei of opposite sex at their origin.

The perithecia lack true paraphyses but large, irregular thin-walled cells present among the asci, are similar to those described by Cain (l.c.) in ascocarps of G. reticulospora and G. calospora.

This fungus agrees with the description of $G$. cerealis which had been isolated only from the crowns of wheat and oats. Despite the difference in hosts, it appears to be identical with Gelasinospora cerealis Dowding.

This is a new host record for this species and the first record of the occurrence of this genus in South Africa.-G. C. A. v. d. W.

2. Spegazzinia tessarthra (B. \& C.) Saccardo in Syll. Fung. 4: 758 (1886); Damon, Bull. Torrey Bot. Cl. 80: 162 (1953).

Figures: 5, 6 .

Colony on malt agar slow-growing, up to $75 \mathrm{~mm}$ in diameter after 5 weeks at $25^{\circ} \mathrm{C}$. Mycelium submerged, hyaline, branching, thin-walled, septate; fertile hyphae in sporodochia, simple, fuscous, ascending, elongate or reduced, bearing single, terminal conidia ; sporodochia separate, scattered, up to $1 \mathrm{~mm}$ in diameter; conidia fuscous, four-celled, the cells arranged in the form of a Maltese cross, thin-walled, dark, smooth, 12-16 $\times 6-$ $8 \mu$, or strongly echinulate, $16-24 \times 8-14 \mu$, spines $2 \cdot 0-10 \mu$.

Specimens examined: PRE 43723, on malt agar, isolated from Zea mays seed, Lichtenburg, Transvaal, June 1966; PRE 36958 on wood of Acacia mearnsii, Atholl Experiment Station, Natal, February 1949; PRE 10003, Fungi Malayana No. 289, on Oryza sativa, Mt. Maquiling, Laguna Province, Philippines.

The material described here agrees well with the description by Damon (l.c.). The South African isolates are closely similar to the Philippine material, determined by Saccardo (l.c.), in our herbarium. Of interest here is the occurrence of one South African specimen on wood of Acacia mearnsii which differs from Damon's (l.c.) statement that this fungus is common on decaying monocotyledonous plant parts.

Another species of the genus, Spegazzinia meliolae Zimm., is recorded by Doidge (Bothalia 5, 731, 1950) on various species of Meliola and related genera in South Africa.G. C. A.v.d. W. 
3. Melampsora larici-populina Klebahn, in Zeitschr. f. Pflanzen-krankh. 12:43 (1902); Sydow, Monographia Uredinearum 3: 346 (1915); Gremmen, Tijdschr. Plziekt. 60: 245 (1954); Gäumann, Beitr. Kryptogamenfl. Schweiz 12: 132 (1959); Hennebert, Agricultura 12;661-670 (1964).

Figures: 7,8 .

Uredosori hypophyllous, causing pale, greenish yellow spots on the upper surfaces, mostly in scattered groups over the entire lower surface, small, up to $1 \mathrm{~mm}$ in diameter, at first covered by the raised epidermis, later surrounded by the broken epidermis, powdery, orange-yellow to golden-yellow; uredospores oblong to oblong-obovoid, $30-42 \times 15-20 \mu$, golden yellow to orange-yellow in mass, smooth at the apex but markedly echinulatespinulose towards the base, the wall colourless, $2-3 \mu$ thick but thickened equatorially to $6-9 \mu$ resulting in a dumb-bell shaped lumen; paraphyses pyriform capitate $44-96 \mu$ long, the upper part $15-20 \mu$ in diameter with wall up to $15 \mu$ thick in the uppermost part, decreasing to $3-4 \mu$ in diameter along the thin-walled stalk.

Specimens examined: PRE 43694 on Populus deltoides, Waterkloof, Pretoria, Transvaal, March 1967; PRE 43691 on Populus deltoides hybrids, Pietermaritzburg, Natal, February 1967; PRE 43692 on Populus sp. (Chilean poplar), Pietermaritzburg District, Natal, February 1967.

This rust species had not been seen in South Africa before but the specimens cited above were brought to the author's attention within three weeks of one another during the very wet late summer of 1967. It is the second rust species recorded on Populus spp. in South Africa. The other species, Melampsora aecidioides (D.C.) Schroet. had been recorded by Doidge (Bothalia 5:394, 1950). M. aecidioides differs from M. laricipopulina by its smaller ovoid uredospores which have their walls evenly thickened and small echinulae evenly distributed over the entire surface. Its uredosori are pale yellow in colour.

As described here, the South African collections agree well with the descriptions by Sydow (l.c.), Gremmen (I.c.), Gäumann (I.c.) and Hennebert (l.c.). The paraphyses of the South African material are larger than the dimensions given by Gäumann but agree with those of Sydow. The identity of this fungus was kindly confirmed by Dr. G. L. Hennebert of the Catholic University of Louvain, Belgium.-G. C. A. v. d. W.

4. Saccobolus depauperatus (Berk. \& Br.) Phill. in Brit. Discom. 296 (1887); Seaver, F.J. The North American Cup Fungi (Operculates) 95 (1942).

Figures: 9, 10, 11, 12.

Apothecia scattered or gregarious, superficial, attached by short central stipe only, minute, rarely exceeding $250 \mu$ in diameter, smooth, hymenium plane or slightly convex, usually hyaline but occasionally with dilute violet pigment in the sub-hymenial layers or with a yellow pigment in the paraphyses; asci clavate with truncate apices, operculate, narrowing to slender bases, hyaline, eight-spored, $55-80 \times 15-20 \mu$, interspersed with paraphyses; spores at first loosely dispersed in the apex of the ascus, finally uniting into an elongated spore mass, $30-40 \times 12 \cdot 5-14 \cdot 0 \mu$; individual spores at first hyaline, darkening through deep violet to brownish violet, appearing black by reflected light, ellipsoid with narrowed ends, smooth or occasionally pitted, $12 \cdot 5-14 \cdot 0 \times 5-7 \cdot 5 \mu$; paraphyses septate, slender, hyaline or occasionally coloured, reaching a diameter of $3-4 \mu$.

Specimen examined: PRE 43901 (Mycological Herbarium), dried apothecia on horse dung, Onderstepoort Veterinary Research Institute, Oct. 1967.

Although the apothecia examined do not agree in every detail with the description of $S$. depauperatus, they are nevertheless considered to be representative of this species. The observed differences, viz. the absence of the lilac colour in the excipular cells, the 
larger variation in size of the asci and the slightly larger ascospores and spore-clusters, are not considered to be sufficient to warrant the proposal of a new species. The variation in the colours observed is considered as expressive of strain differences and not of specific differences. The observation by Berkeley and Broome (Ann. Mag. Nat. Hist. III. 15. 1865) that the apothecia are yellowish when young, could have been due to the yellow pigment in the paraphyses being more noticeable during the stages preceeding ascospore maturity.

This species has been found on horse dung from different localities in the Transvaal and Natal and appears to be widespread.

This is the first record of the occurrence of this genus and species in South Africa. -K.T. v. W.

5. Humicola stellata Bunce in Trans. Brit. Mycol. Soc. 44: 372-376 (1961); Cooney, D. G. and R. Emerson. Thermophilic fungi. W. H. Freeman and Co. London. 80 (1964).

Figures: 13, 14.

On naturally infected grass the mycelium is hyaline, smooth-walled, regularly septate, not constricted at the septa, $1 \cdot 2-1 \cdot 4 \mu$ in diameter; conidiophores hyaline, aseptate, smooth-walled, arising from a hyphal cell, without basal septum, $2 \cdot 0-9 \cdot 4 \times 1 \cdot 4-2 \cdot 7 \mu$; conidia unicellular, hyaline, becoming dark brown at maturity, appearing black by reflected light, may be sessile on the vegetative mycelium or borne on conidiophores, spore wall thickening slightly with age, smooth, extremely variable in shape, ranging from ellipsoid to tetrahedral to cuboid to stellate, older spores usually with a prominent single refractive globule.

Specimen examined: PRE 43881 (Mycological Herbarium), colonies on dried grass hay, Johannesburg District, June 1967.

This fungus was found on bales of dried veld hay which had been exposed to rain. It was found at this locality only and is the first record of the occurrence of this genus and species in South Africa.-K. T. v. W.

6. Chaetomium cochliodes Palliser in N. A. Flora 3:61 (1910); Ames, L. M. A monograph of the Chaetomiaceae. U.S. Army Res. and Dev. Ser. 2. 17 (1963).

On potato-malt-cellulose agar (Ames, l.c.) aerial mycelium is lacking. Perithecia numerous, ostiolate, subglobose, greyish green to yellow-green, attached to the substrate by dark rhizoids, seldom producing cirrhi, $300-355 \times 265-312 \mu$; terminal hairs numerous, of two types: (1) thick, dark brown, paling towards the tips, slightly roughened, with few terminal convolutions; (2) thin, olivaceous or lighter, undulate or coiled; lateral hairs numerous, dark brown, paling towards the tips, straight, slightly roughened; asci deliquescing before spore maturity, clavate, hyaline, eight-spored, 80-95 $\times 9-12 \mu$; ascospores hyaline when immature, darkening to olive brown at maturity, irregularly biseriate, ellipsoid, bi-apiculate, $8 \cdot 0-9 \cdot 5 \times 6-8 \mu$.

Specimen examined: PRE 42931 (Mycological Herbarium), dried culture, isolated from garden soil, Pietermaritzburg, Natal, Sept. 1962.

This is the first record of the occurrence of this species in South Africa.K. T. v. W. 